\title{
Viability of Muzara'ah Contract on Agro-financing in Alleviating Rural Poverty in Kano State, Nigeria
}

\author{
Bello Sani Yahuza \\ International Institute of Islamic Banking and Finance (IIIBF), Bayero University, Kano-Nigeria, \\ email: bsyahuza.iiibf@buk.edu.ng; bellosaani@gmail.com
}

\begin{abstract}
The problem of inadequate sources of financing agriculture and the scarcity of credit facilities to rural farmers due to interest rate and lack of collateral or guarantor to secure loans lead to many lands becoming fallow especially in dry season. This adversely affects the entire yield in the rural areas in Kano State. This paper assesses the viability of muzara'ah in providing sources of agro-financing and alleviating rural poverty. This study conducted in Kura LGA Kano State, adopted a quantitative survey method, 152 samples out of 250 registered farmers were used, using random sampling, questionnaire for data collection and chi-square test for goodness of fit for analysis. The paper finds the viability of muzara'ah in providing sources of agro-financing very significant as it bridges the gap that exists between the surplus and the deficit landowners where the former offers his surplus land to the latter and employed his labor to till the land and share the yield on a pre-agreed ratio. The paper recommends the proper implementation of muzara'ah to cultivate more lands, generate job creation, increase farmers income earning, and enhance food security which, in turn, alleviates rural poverty.
\end{abstract}

Keywords: Agro-financing, muzara'ah, rural poverty

JEL Classifications: Q14, I39

\begin{abstract}
Abstrak. Sumber pembiayaan pertanian yang tidak memadai serta kelangkaan fasilitas kredit kepada petani pedesaan dapat terjadi karena tingkat bunga dan kurangnya jaminan atau penjamin untuk mendapatkan pinjaman. Hal ini menyebabkan lahan menjadi terbengkalai terutama di musim kemarau. Keadaan tersebut berdampak buruk terhadap hasil panen di daerah pedesaan di Kano. Penelitian ini menilai kelayakan pembiayaan model muzara'ah bagi pertanian dan kelayakannya dalam mengurangi kemiskinan pedesaan. Penelitian ini dilakukan di Kura LGA Kano State, dengan mengadopsi survey kuantitatif, menggunakan sebanyak 152 sampel dari 250 petani terdaftar, random sampling, dan kuesioner untuk pengumpulan data serta uji chi-square untuk goodness of fit dalam menganalisisnya. Studi menemukan bahwa model muzara'ah layak dalam menyediakan sumber pembiayaan pertanian serta hasilnya sangat signifikan karena menjembatani kesenjangan yang ada antara kelompok surplus dan kelompok defisit pemilik lahan, karena kelompok surplus menawarkan kelebihan lahannya untuk diolah serta mempekerjakan tenaga kerjanya untuk mengolah tanah dengan rasio bagi hasil yang telah disepakati sebelumnya. Rekomendasi yang dapat diberikan adalah implementasi muzara'ah yang tepat dan digunakan untuk mengolah lebih banyak lahan, menghasilkan lapangan kerja, meningkatkan penghasilan pendapatan petani, dan meningkatkan keamanan pangan yang, pada gilirannya, mengurangi kemiskinan pedesaan.
\end{abstract}

Kata kunci: Pembiayaan pertanian, muzara'ah, kemiskinan pedesaan

\section{INTRODUCTION}

Agriculture and food security go hand in hand; one cannot be achieved at the expense of the other. They are the key derivers for alleviating rural poverty to the global community's concern with the passage of the Millennium Development Goals (MDGs) and now the Sustainable Development Goals (SDGs) bidding to eradicate extreme poverty and hunger by enhancing food supply at global and regional levels. According to the World Bank (2013), agriculture alone employs 65\% of Africa's labor force. The Global Food Security Index puts Sub-Saharan Africa (SSA) countries at the bottom of the food security rankings (GFSI, 2015).

Nigeria, however, blessed with great natural endowments and a huge land, labour and market potentials, the underperformance of agricultural sector due to many factors has heavily affected the food security situation in the country. As such, land is not adequately cultivated, domestic crop 
outputs are little to satisfy the teaming population in the country, food prices are hyper inflating; the country's food sources are imported from the foreign market which adversely affected the country's balance of payment at macro level at the expense of the export earnings.

Moreover, as the food imports bill grows at $11 \%$ per annum, the total annual imports bill reaches nearly $\$ 22$ billion per annum. The major setback for agricultural development in Nigeria is the scarcity, inadequacy and inefficiency of financing resources, the annual budget's share of agriculture is always inadequate to cater for the total demand of the sector's financing resources. Recently, the $1.6 \%$ translated to $\$ 92$ billion share of agriculture from total $\$ 6.06$ trillion in the 2016 annual budget allocation buttresses this assertion, forcing the current Minister of Agriculture to disclose it as inadequate (Ekhege, 2016).

Ironically, the trend continues with the 2017 annual budget's share to the sector, albeit is slightly increase to $\$ 103$. Seven billion from the total $\$ 7.441$ trillion also adds to the inadequacy of the financing resources (Agronigeria, 2017). The release and utilization of the fund is untimely and in most cases unachievable, as such most of the Federal Government policies on agriculture have had limited impact and food security has not been achieved and poverty, hunger and unemployment increased as general economic performance of the GDP registers negatively in the $3^{\text {rd }}$ quarter of 2016 to -2.24 (Ministry of Budget and National Planning, 2016).

Consequently, the current performance of the agricultural sector's contribution to the overall GDP in the $3^{\text {rd }}$ quarter of 2016 was $28.65 \%$ which is a strong indication that the country is already in food and economic crisis and Nigeria is now among the 39 Low-Income-Food-Deficit Countries (LIFDCs) (FAO, 2018). Thus, the incumbent government focuses its economic recovery and growth at diversifying the mono-oil-economy, which crashed in the global market and sets agriculture to be one of the key derivers of its economic policies. But the shift from subsistent to commercial agriculture requires funding as the financial institution's lending to agriculture remains as low as $1 \%$ in many parts of Africa (Ruete, 2015).

Agriculture is essential for Sub-Saharan Africa's growth and for achieving Sustainable Development Goals with the passage Millennium Development Goals of halving poverty by 2015. Agriculture alone employs $65 \%$ of Africa's labor force (World Bank, 2013) being the largest labour employer, provider of raw materials to industries and boosting export and exchange rate earnings are just some incentives of the sector (Eze et al., 2010; Agbaeze \& Onwuka, 2013).

Likewise in Nigeria, where the agricultural sector as the most important non-oil economic activity employs $70 \%$ of labor forces and contributes $40.07 \%$ of GDP (NBS, 2010). The sector up to the 1960s was the main pillar of the Nigerian economy providing enough food to the citizens and at the same time export the surplus food items to the foreign market, for instance; the famous groundnut pyramids in the Kano in the North, cocoa in the west, oil palm and kernel heaps in the East, and the rubber plantation in the Mid-west asserts the notion (Adebayo \& Ojo, 2012).

However, the sector was eventually neglected due to oil discovery and subsequently the country became one of the major food importers, to buttress the assertion Nigeria never meet the $10 \%$ minimum annual budget requirement to agriculture as recommended by 2003 Maputo Declaration, the highest was $7 \%$ in 2008. Thus, the greatest challenge to agriculture in Nigeria, no doubt, has been inadequate funding (Okoro \& Ujah, 2009; Agbaeze \& Onwuka, 2013).

Nevertheless, the problem of inadequate funding through low budget allocation to the agriculture by the successive regimes of the Nigerian government resulted into many problems such as: inadequate funds for credits and inputs supply to rural farmers, and lack of storage facilities to manage postharvest loss. Perhaps, some agricultural policies were launched by the Nigerian government since 1950s to date such as the Agricultural Development Programme (ADP-1975), Operation Feed the Nation (OFN-1976), the Green Revolution (1980) FADAMA I, II and III, the Agricultural Credit 
Guarantee Scheme Fund and so on (Adetiloye, 2012) aimed at providing adequate financing resources, but only the contrary was achieved. As such, the low crop yield is not enough for the rural farmers to meet their annual demand of food consumption let alone provide the surplus to the market.

In fact, this problem proves the strong nexus between agricultural financing and achieving food security in alleviating rural poverty which, is defined by Adeleke (2012) as a situation where individual or a community cannot afford the basic necessities of life such as food, clothing and shelter. Poverty causes hunger and vice-versa (FAO, 2008). Statistically, 75\% of the world's poorest people live in rural areas, $98 \%$ of the world's undernourished people live in the developing countries and $42.3 \%$ of the poor Sub-Saharan Africans (SSA) lives on less than $\$ 1.90$ a day including Nigeria (World Hunger and Poverty Facts, 2018; The Hunger Program, 2018). Although, about $75 \%$ of the working population in Kano State was committed to agriculture (Kano State, 2013), but $73.11 \%$ of its total population are poor and food insecure (NBS, 2013) and about $73 \%$ of its households are living below $\$ 1.25$ a day which, reflects the severity of poverty especially in the rural areas in the state. The crop output is insufficient to the level of consumption as a result of low income earning by the farming households (Ifeoma \& Agwu, 2014).

According to Makarfi and Olukosi (2012) and Ejike (2012), the difficulty of rural farmers to access formal loans due to interest rate, lack of collateral, guarantor, high cost of loan application and so on forced the farmers to resort to informal source of financing ranging from personal income, borrowing from friends, relatives, money lenders, farmers cooperatives, self-help groups and equity, which is insufficient and cannot meet the demand of commercial agricultural financing. Majority of farmers in Kano State especially in rural areas is subsistent (Makarfi \& Olukosi, 2012) and most of the farming system is rain-fed but irrigated farming is also practiced, and rice was identified as the main staple food of its populace (Inuwa et al., 2011). Therefore, accelerated agricultural and rural development would contribute to greater efficiency, increase household income, improve standards of living, and reduce poverty (Nyagba, 2009).

Whereas, muzara'ah is defined as sharecropping partnership or joint act of farming. Technically, muzara 'ah (share-cropping) is a type of agricultural partnership contract where the contracting parties agreed to contribute between the factors of farming production and share the yield on a pre-agreed ratio after harvest (Yaacob, 2013). The great potentials of muzara'ah contract in terms of providing financing opportunities to rural farmers are very important, where landowners provide their lands to landless farmers and employ their labor to cultivate it, which help in cultivating more lands and, in turn, alleviate rural poverty in Kano State.

Consequently, empirical studies prove the practice of muzara'ah as beneficial in countries like: Malaysia, Indonesia, Egypt, Yemen, Sudan, Pakistan et cetera, particularly in rice farming, either by governments in their policy to enhance food security or by commercial institutions and other corporate bodies, the practice proved successful in alleviating poverty, promoting food security, achieving economic well-being of farming society, social brotherhood, and justice (Khasanah et al., 2013). This objective of food security and social wellbeing is articulated by the Quran Al-Balad verses 14-16, thus: "...Or providing food in a day of hunger (famine), to an orphan near of kin, or to a Miskin (poor) cleaving to dust (out of misery)".

Therefore, the paper underscores the viability and potentials of muzara'ah (sharecropping) mode of agricultural financing in alleviating rural poverty and providing food security by facilitating financing opportunities to the rural farmers in Kano State and Nigeria in general, thus the findings of the paper would provide positive solution to the policy makers, public and private institutions.

\section{Research Objectives}

The broad objective of the paper is to assess the viability of muzara'ah on agro-financing in alleviating rural poverty in Kano State. Other specific objectives are to: 
1 Assess the viability of muzara'ah contract in providing alternative source of financing agriculture in Kano state;

2 Determine the potentials of muzara'ah contract in alleviating rural poverty in Kano State.

\section{Research Hypothesis}

$\mathrm{H}_{0}$ : Muzara'ah contract does not have significant potentials towards providing source of agrofinancing and alleviating rural poverty in Kano State.

\section{LITERATURE REVIEW}

\section{Conceptual and Theoretical Clarifications}

Muzara'ah has been defined by different classical jurists such as: Qurafi “d. 1285/684AH" (1994), Ibn Manzur (d. 711AH/1311CE), Hakimi (2011), Fiqh Encyclopedia (1997 CE/1418 AH) and Sharbisi (1401/1981). Literally, muzara'ah is an Arabic word which denotes partnership on farming or joint act of planting. Technically, to the Hanafis, muzara'ah is a contractual agreement on farming against a pre-agreed share from the crop outputs. To Malikis, it is a joint partnership on crops (Dusuqi, V. 3 p. 372; Zuhaili, 1985); to the Shafi' is it is an agricultural work on land for a share from the outputs with the seeds from the landowner (Fiqh Encyclopedia, 1997), whereas to the Hambalis, muzara'ah is a provision of land to a peasant to work on it to share a specified known portion from the output produce (Ibn Qudamah, 541-620 A.H, 1997).

In general, muzara'ah known as a sharecropping contract is an agreement between two parties in which one agrees to allow a portion of his land to be used by the other in return for a part of the produce of the land (Yaacob, 2013). Sharecropping contract has been applied to finance agriculture where the landlord provides the land and the tenant provides the other inputs (seeds, labor, fertilizers, etc.). The landlord receives a share in the crop for the provision of land and so the labor for his work. In extreme cases, such as when the crop is lost, the landlord will forgo his expected returns, but he will not lose his capital because the land is not destroyed or lost physically (Nienhaus, 2010).

However, muzara'ah contract may be in two-party, three-party forms or above (Dusuqi, n.d., p. 372 and Ibn Qudamah 1997, p. 581 and Kasani, 1968, p. 3808 in Hakimi, 2012). Muzara'ah is legally valid contract proved by Sunnah ${ }^{1}$, Ijma' and Qiyas and accepted by all the scholars except Abu Hanifah and Zufar bn Hudhayl (110-158AH). Muzara'ah complements the legal maxims of promoting public interest (maslahah), removal of difficulties, social brotherhood, equity, and participation.

\section{Conditions and Termination of Muzara'ah Contract}

Muzara'ah contract should meet certain rules and regulations before it could be considered a legally valid contract. Scholars of fiqh, such as Maliki, Hambali, Hanafi, etc., summarized those conditions as: (1) competency of the parties to muzara'ah contract, 2) offer and acceptance must be clearly expressed and agreed upon by the parties, 3) providing land to the farmer, 4) fertility and freeing the land rent paid from the land produce, 5) sharing of the output, 6) specification of period of muzara'ah, 7) specification of each party's share and justification based on the equity share of the parties, 8) specification of the type of the seeds and, 9) Specification of who is to provide seeds (Al-Aini, 1990CE/1411AH) (Kasani 1968: 3822 in Hakimi, 2012).

\footnotetext{
${ }^{1}$ Imam al-Bukhari (d. 256AH) reported that, Qais bn Muslim related from Abu Ja'far who said: There is no household from the emigrants (Muhajirun) in Medina, save they are practicing muzara' 'ah on $1 / 3$ and $1 / 4$, and Ali (RA) did muzara'ah, also Sa'ad bn Malik, Abdullahi bn Mas'ud, Umar bn Abdul'aziz, Qasim, Urwat, the families' of Abubakar (RA), Umar (RA), Ali (RA) and Ibn Sirin all have been practicing muzara'ah contract. Abdul-Rahman bn al-Aswad said: I used to partner Abdul-Rahman bn Yazid in sharecropping. Also Umar (RA) used to partner peasants on condition that, if Umar provide the seeds he will get $1 / 2$ share from the yield, but if they provide the seeds they get so and so.
} 
However, the contract could automatically be terminated when the period is completed, otherwise it could be ended by expressing word of termination by either party, or by action, e.g. when the farmer died or denied access to the land (Zuhaili 1985: 626-627). Also muzara'ah is terminated when the landowner run into bankruptcy that necessitates the land to be liquidated or when the farmer refuses to work in the land provided that will not incurred any loss to the landowner.

\section{Agricultural Financing}

However, agriculture according to Ken (2006 as cited in Yusoff, 2013) by narrow definition means farming, and by broad definition, it is an activity which relates to the production process of human needs, which originated from plants or animals, accompanied by efforts of renew, reproduce and reconsider economic factor. Agricultural financing is defined as the economic study of acquisition and use of capital in agriculture that deals with the supply of and demand for funds in the agricultural sector of the economy. Whereas, Famogbiele (2013) stated that agricultural finance is all about the acquisition and utilization of capital with the factor of production that facilitates the acquisition, procurement and management of the other factors of production namely, land, labour, capital, and entrepreneur to improve social welfare through development of agricultural sector for rural development, income equality, and local empowerment in a form of equity, gift, or loan.

Obansa and Madueke (2013) cites scholars like Antonio and Agnes (1994), Mody (1981), Rao (1978), and Narayan (1994) arguing that developing countries (Nigeria inclusive) are in dire need of longterm mode of agricultural financing, as a stage of their respective economic development. Different types of agricultural financing, such as rural financing, value chain agricultural financing, microfinance agricultural financing, etc. all are of equal importance to rural development and rural poverty eradication.

\section{Rural Poverty}

The common manifestation of rural community is poverty. In fact one cannot separate poverty with rural people. Hence rural poverty becomes a popular concept among the scholars which is ever increasing. The statistics says that $75 \%$ of the world's poorest people live in rural areas, $98 \%$ of the world's undernourished people live in the developing countries and $42.3 \%$ of the poor Sub-Saharan Africans (SSA) lives on less than $\$ 1.90$ a day including Nigeria (World Hunger and Poverty Facts, 2018; The Hunger Program, 2018). Nigeria with all her abundant natural, material, and human resources is classified among the top 25 poorest nations with about $70 \%$ almost $2 / 3$ of her citizens under poverty line (Adeleke, 2012). Also, Ajulor (2013) and Egwemi and Odo (2013) state that, studies have shown that majority of Nigerians live in the rural areas and are deprived of basic facilities. While the statistics vary in terms of the actual number of people in the rural areas; $70 \%$ (Aderonmu, 2010); 75\% (Abubakar, 2009); 73\% (Dauda \& Aderonmu, 2010); 73\% (Presidential Report, 1999) are however, in agreement to the extent that most Nigerians live in the rural areas and majority of them are poor and subsistent farmers.

Adding to that are: lack of infrastructure such as roads, telecommunication facilities and postal services, lack of constant power and water supply, storage facilities, farm mechanization and technological advancement, lack of convenient and conducive atmosphere for learning, poor health care centers and facilities, scarcity of access to land and sources of financing, widening rural-urban income gap which resulted in rural-urban drift, large family size and so on, that is why poverty and rural existence are two faces of a single coin thus, any attempt to tackle the menace of poverty in Nigeria must focus on the rural areas. To sum it up, the root problem of inadequate access to food is poverty (Yakubu \& Aderonmu, 2010; Ajulor, 2013; Egwemi \& Odo, 2013).

However, poverty may be absolute, relative, or subjective poverty. Absolute or subsistent poverty refers to a situation where there is a lack of basic necessities of life such as: food, clothing and shelter, relative poverty refers to person whose resources are low in relation to another person, meaning he is 
considered poor only in relation or comparison to other person, and the subjective poverty which is defined as a minimum income earning which people consider necessary to make ends fulfilled for household. Subjective poverty exists when the level of one's income failed to meet one's needs, therefore, before concluding one is subjectively poor factors like family size, age, education, occupation, gender, religion and so on must be taken into cognizance (Egwemi \& Odo, 2013).

\section{Rural Development}

The concept and definition of rural development vary among the scholars. While some scholars defined it signifying sustainability of utilizing resources, some signify political process through democracy, justice and equity of rural populace and gender sensitivity; others signify economic development by improving standard of rural population, agricultural development, employment generation and infrastructure. Egwemi and Odo (2013) outline five definitions on rural development:

Adegboye (1973) sees rural development as "the development of rural people in such a continuous manner as to enable them to most effectively and efficiently utilize their intellect, technology and other resources for further development of themselves and others". Similarly, the south African Rural Development Framework (SARDF, 1997:9) defines rural development as "helping rural people set the priorities in their own communities through effective and democratic bodies by providing the local capacity, investment in basic infrastructure and social services, justice, equity and security, dealing with the injustices of the past and ensuring safety and security of the rural population, especially that of women". To Diejomaoh, (1973:98) rural development is "a process of not only increasing the level of per capita income in the rural areas but also, the standard of living of the rural population". Whereas Gana, (1990) views rural development as "the re-structuring of the rural economy so as to lift it from being a dependent peasant and largely agricultural to one economy capable of sustaining the quality of life. It is a process of bringing improved level of living to the rural population with notable and reasonable changes at all levels". And lastly, Akinbode, (1987) conceives rural development as "involving a spectrum of issues among, which are the problems of agricultural mechanization, job creation, transport development and provision of adequate housing and shelter for the rural dwellers".

However, the central point to consider in all the above definitions is that rural development is about enhancing and improving the socio-economic living standard of the rural population through agricultural transformation plans. The great potentials of the rural areas are very vital to the socioeconomic development in the sense that it provides agricultural products, food stuffs, labor employment, mineral resources and raw-materials for internal and external industries. These are indeed very crucial to the attainment of poverty alleviation, sharing economic growth and sustainable development to individuals, household and the country as a whole. It is pertinent to know that rural population comprises local farmers, laborers, tenants and sharecroppers thus; the paper argues that rural development is a veritable vehicle of poverty eradication in Nigeria (Egwemi \& Odo, 2013). Experience from the developed economies has shown that a sound rural development policy must possess these three key fundamental elements, viz: must be sustainable, efficient, and affordable (Nyagba, 2009).

\section{Empirical Framework}

Rahman and Othman (2012) conducted their work in Selangor State, Malaysia, the study identifies the people of Malaysia as Shafi'i Mazhab adherents who practice muzara'ah sharecropping and pay zakah tithe. They share seeds, fertilizers, pesticides, transport, and labor costs by adopting Hanafi views. They rent land at the rate between RM100 to RM900 per acre, which in Nigeria is $\$ 25,000$ per acre. Rahman and Othman (2012) also explain that Fatima (1983), suggests that, in sharecropping known as Pawah in Malay language, farmers get $\mathbf{1 / 2}$ ratio or $\mathbf{2 / 3}$ ratio. While Fatima (2004), on the other hand found out in Kelantan that farmers rent out land for paddy cultivation at RM 53.00 per acre. 
Another is work by Yaacob (2013) on commercializing muzara'ah model between Malaysian government and Orang Asli people. The study proposes the Malaysian government to provide access to land to the Malaysian aborigines to cultivate and share the yield between government and them. The study concludes the findings as: 1) muzara'ah model assists both government and the aborigines, 2) the model instilled a humanistic sense in Malaysian government policy. Giving compensation will merely works in short term. Apart from compensation, their skills need to be instilled for long term survival, and 3) the model also suggests that government is a caring institution and consequently evading all negative accusation on the treatment of Orang Asli.

Meanwhile in Sudan, the Sudanese Islamic Bank (SIB) adopted muzara'ah financing partnership in three different farming patterns, namely: canal irrigation, pump irrigation, and rain-fed, the Bank provides fixed assets, such as tractors, ploughs, harrows, water pumps, and inputs e.g. seeds, fertilizers, pesticides, fuel, jute sacks and co-management, marketing, storing, and extension. The farmer on the other hand contributes with his land, labor and management. From the net profit the farmer gets $30 \%$ for management. The remaining profit (70\%) is divided between the Bank and the farmer according to their equity share (Al-Harran, 1990).

Similar studies were conducted in Pakistan by Hassan et al. (2012) and Tahir (1996). The former's is titled; Role of Islamic Banking in Agriculture Development in Bahawalpur, Pakistan. Using standard deviation, variance, and Chi-square tests, the study concludes that muzara'ah among the range of Islamic banking products, should be used to address the farmers' credits constraints in the region. The latter's proposes shari'ah compliant muzara'ah as a relevant mechanism to replace the exploitationbased and riba-associated land-tenancy among landowners and tenants.

More so, Hakimi, (2011) conducted his own in Egypt on the theory of muzara'ah and musaqah and their contemporary application in Tanta agricultural district. The contemporary scholars' and practitioners' views in Azhar and Cairo universities and Faisal Bank Library and Saleh Kamel Islamic Economics Research Centre were analysed. The study concludes that both muzara'ah and musaqah are suitable mechanisms in agricultural investment as they stand to help both parties as well as its immense role in reactivation of an idle land as they help in cultivating more land.

Meanwhile, a research work conducted by Khasanah et al., (2013) in Indonesia finds that the profit and loss sharing (PLS) practice covers partnership as a work basis, the priority of equity capital, the one-third share and one-half share models which is based on equality, prosperity, mutual cooperation, and ta'awun (mutual assistance). On the whole, the practice proves immensely successful and beneficial to government, private sector and individuals including the rural farmers.

\section{METHOD}

\section{Overview of The Study Area}

Kano State represents the entire population under study. Kano was one of the original seven Hausa Kingdoms; the city was founded around the $6^{\text {th }}$ century C.E. and located in the North Western Region of Nigeria. The modern Kano State was created on May 27, 1967 from part of the Northern Region and became the largest city in Nigeria as at 2006 census with population of 9,383,682, estimated populations reached 12 million in 2013. The State bordered with Katsina State to the north-west, Jigawa State to the north-east, Bauchi State to the south-east, and Kaduna State to the south-west. The length of the state is more than 18,684 square kilometers $(7,214 \mathrm{sq} \mathrm{mi})$ or more than three million hectares of cultivable land and is the most extensively irrigated state in the country and the second largest state in terms of commercial activity. The English and Hausa were the two official and local languages spoken respectively in the State. It has 44 local government areas and 483 wards (Kano State, 2013). 
The State contributes over $20 \%$ of Nigeria's non-oil export revenue. Agriculture is one of the most important pillars of the State's economy with about $75 \%$ of the total working population engaged directly or indirectly in it. The principal food crops cultivated in the state are millet, cowpeas, sorghum, maize, and rice. Also groundnuts, wheat, cotton, sesame, soya beans, cotton, garlic, gum Arabic, and chilli pepper are produced for consumption, export and industrial purposes. Most of these commodities are available at the famous Dawanau Market about 13 kilometers from the Kano City (Kano State, 2013).

Furthermore, the state has three agricultural zones, namely: Rano zone one, Dambatta zone two and Gaya zone three. The Rano zone, the largest rice producing zone has 14 local government areas: Rano, Kura, Garun Malam, Tudun Wada, Kumbotso, Bunkure, Bebeji, Kiru, Doguwa, Kibiya, Madobi, Rogo, Karaye, and Gwarzo local government areas.

\section{Materials and Methods}

The paper employed an exploratory quantitative survey design. Kano State farmers are the population of study from which Kura Local Government Area is the focus of the research. A multi-stage random sampling technique was used to select 152 samples of the registered farmers. The procedure started at primary level by selecting Rano Agricultural Zone I from the three agricultural zones in the State. The researcher was formally introduced to the Area Programme Coordinators (APCs) in the study area. The researcher with the help of four research assistants administered the instrument to the respondents and allowed an interval of three to seven $(3-7)$ days for retrieval. Three of the research assistants (APCs) are agricultural staff working under the Rano Zone and the other one is a local farmer. The researcher successfully retrieved 364 questionnaires out of the 380 distributed questionnaires issued to the target respondents and the relevant information was collected.

Muzara 'ah Agricultural Financing Scale (MAFS) was the structured questionnaire used for collecting primary data from the target respondents in Kura Local government area from the total sample size of 250 farmers. Furthermore, Chi square test of goodness of fit was adopted for data analysis and justified in line with the previous researchers, such as Hassan et al. (2012).

\section{RESULTS AND DISCUSSIONS}

The paper through the presentation of data and discussion of the results aimed at exploring the viability of muzara'ah (sharecropping) contract on agro-financing to alleviate rural poverty in Kano State,Tthe discussion of the data is as follows:

$\mathrm{H}_{0}$ : Muzara'ah contract does not have potentials towards providing source of finance and alleviating rural poverty in Kano State.

Table 1 below shows farmers' responses on each item. To test the null hypothesis, six itemized potentialities of muzara'ah contract were identified by the respondents in the study area. The p-value $(0.002)$ is less than the level of significance $(0.002<0.05)$ at 5 degrees of freedom which shows a significant difference with respect to the six items. This implies that some potentialities are significantly more important than the others. An observation of the data reveals that items (2), (3), and (5) are significantly more viable than others in terms of providing source of finance and alleviating rural poverty.

Table 2 shows responses about major challenges of farming system in the study area as identified by the respondents to test the null hypothesis. The p-value $(0.00)$ at 5 degrees of freedom is less than the level of significance $(0.00<0.05)$ which shows a significant difference with respect to the five items. Therefore, an observation of the data reveals significant difference among the five items which inferred that some challenges are more significant than others. Item (1) which is inadequate sources of financing is more severe than the rest, followed by item (4) land tenure and item (3) scarcity of inputs respectively. 
Table 1 Chi-square test of goodness of fit showing the most dominant potentials of muzara'ah contract towards providing source of financing agriculture and alleviating poverty in the study area as identified by the respondents

\begin{tabular}{clc}
\hline S/No & Observations & Observed N \\
\hline 1 & $\begin{array}{l}\text { Encourages more uncultivable land to be cultivated by providing more } \\
\text { access to surplus land }\end{array}$ & 55 \\
2 & $\begin{array}{l}\text { Provides more sources to agro-financing } \\
3\end{array}$ & 73 \\
& $\begin{array}{l}\text { Creates job opportunities, reduces unemployment rate, enhances economic } \\
\text { full employment, and achieve macroeconomic growth and development }\end{array}$ & 73 \\
4 & $\begin{array}{l}\text { Promotes social solidarity, brotherhood, mutual cooperation, and } \\
\text { participation }\end{array}$ & 55 \\
5 & Enhances food security by reducing hunger and alleviating rural poverty & 73 \\
6 & Enhances payment of zakah & 36 \\
\hline & Total & 365 \\
\hline
\end{tabular}

Source: Primary data

Note: P-value $=0.00 ;$ Degrees of freedom $=5 ;$ Level of significance $=0.05(5 \%)$

Table 2 Chi square test of goodness of fit showing the major challenges of farming system

\begin{tabular}{clc}
\hline S/No & Major Challenges & Observed N \\
\hline 1 & Inadequate sources on Agro-financing & 164 \\
2 & Land tenure system & 91 \\
3 & Scarcity of inputs & 73 \\
4 & Lack of party to share the land & 25 \\
5 & Self food secured & 11 \\
\hline & Total & 364 \\
\hline
\end{tabular}

Source: Primary data

Note: P-value $=0.00 ;$ Degree of freedom $=4 ;$ Level of significance $=0.05(5 \%)$

Table 3 below shows farmers' responses on each item. In addition to the below, data analysis six itemized solutions were further identified by the respondents to test the null hypothesis. The p-value $(0.00)$ is less than the level of significance $(0.05)$ at 5 degrees of freedom $(0.00<0.05)$ which shows a significant difference with respect to the six items. This implies that some solutions are more effective than the rest in achieving these potentials. An observation of the data reveals that item (5) is significantly more important than the rest followed by the other items with exception of item (6) which is the least of them.

Table 3 Chi-square test for goodness of fit showing some solutions to the challenges as well as ways of realizing the above identified potentials of muzara'ah contract

\begin{tabular}{clc}
\hline S/No & Solutions & Observed N \\
\hline 1 & $\begin{array}{l}\text { Enlighten farmers on muzara'ah partnership package through programs, } \\
\text { workshops and seminars }\end{array}$ & 54 \\
2 & $\begin{array}{l}\text { Encourage more cultivable land for the farmers by regulating land tenure } \\
\text { system }\end{array}$ & 55 \\
3 & $\begin{array}{l}\text { Formation of muzara'ah partners cooperative society } \\
4\end{array}$ & $\begin{array}{l}\text { Financing support to muzara'ah participants by government and } \\
\text { financial institutions }\end{array}$ \\
5 & $\begin{array}{l}\text { The State and other agricultural institutions should design framework } \\
\text { and regulation for muzara'ah as a means to alleviate rural poverty }\end{array}$ & 109 \\
6 & TAKAFUL (Islamic insurance) & 36 \\
\hline & Total & 364 \\
\hline
\end{tabular}

Source: Primary data

Note: P-value $=0.00$ Degrees of Freedom $=5$ Level of Significance $=0.05$ (5\%) 
Based on the data presented in Table 1 above indicated the potential of muzara'ah in item (2) as a means to provide more source to agro-financing, item (3) creates more job opportunities, reduces unemployment rate, enhances employment, and achieve macroeconomic growth and development, and; item (5) it enhances food security. In Table 2, it indicated among the five items inadequate sources of financing agriculture as the major challenge followed by land tenure system. The data also identified six ways to achieve these potentials in the Table 3, i.e. the need for federal, state and other agricultural institutions to design policy framework (set of rules and regulations, terms and conditions, and modus operandi) for muzara'ah contract as the most important followed by rest with exception of the sixth which is the least.

Therefore, in accordance with the results of the three tables above, the null hypothesis is rejected which says that muzara'ah contract does not have significant potentials in providing agro-financing and alleviating rural poverty in Kano State, and an alternative is accepted which implies that muzara'ah has significant potentials towards providing sources to agro-financing, and alleviating rural poverty in the study area. However, this is in line with classical theories of muzara'ah, and empirical studies of al-Harran (1990), Hakimi (2011), Rahman and Othman (2012), Yaacob (2013), Khasanah et al. (2013) in East Java Indonesia were the farmers practice the profit and loss sharing (PLS) system on rice farming. The study justifies rice as being the common staple food for almost all Indonesians. The farmers who own land cannot do the land tenancy by themselves, so they partner with the sharecroppers. The practice helps in reducing unemployment and increases income earning. And the theories of rural poverty, rural development, and agricultural financing, such as Makarfi and Olukosi (2012), Ejike (2012), Ajulor (2013), Egwemi and Odo (2013), Ifeoma and Agwu (2014), and so on, their studies strongly support the findings of this study.

\section{CONCLUSIONS}

Muzara 'ah contract is a (sharecropping) partnership on agricultural production whereby two or more parties agreed to contribute between land, labor and agricultural inputs to share the expected crop yield on a pre-agreed ratio after harvest. Muzara'ah is an innovative mechanism that can be used as source of finance to empower rural farming populations by providing direct access to land from the surplus landowners to the landless farmers and employ their labor which helps in alleviating rural poverty in Kano State.

However, the study finds muzara'ah contract significantly viable in providing alternative source of agro-financing, creating more job opportunities and reducing unemployment rate by providing more lands to be cultivated which enhances food security and in turn helps in alleviating rural poverty in Kano State, given the fact that the State is agrarian with about $75 \%$ of its population engaged in agriculture.

Therefore, the study strongly recommends that governments at all levels, ministries, commissions for agriculture, and financial institutions through the guidance and regulation of the Central Bank of Nigeria (CBN) should design and adopt a policy framework on muzara'ah comprising rules and regulations on access to land, terms and conditions of the contract, and modus operandi and also laws concerning disputes resolution for the successful establishment of the contract and alleviation of rural poverty as proved by the empirical studies.

\section{REFERENCES}

Adeleke, A. (2012). Improving poverty alleviation programs in Nigeria through small and medium scale agricultural development projects. European Journal of Business and Management, 4(11), 109-119. 
Adetiloye, K.A. (2012). Agricultural financing in Nigeria: An assessment of Agricultural Guarantee Scheme Fund (ACGSF) for food security in Nigeria (1978-2006). Journal Economic, 3(1), 3948.

Agbaeze, K. \& Onwuka, I. (2013). Boosting the financing of agriculture in Nigeria. The capital market option. Research on Humanities and Social Sciences, 3(13), 113-125.

AgroNigeria (2017). Budget: Agriculture sector receives N12bn boost. AgroNigeria Newspaper. [online] Available from: https://agronigeria.com.ng/2017-budget-agriculture-sector-receivesn12bn-boost/ [Accessed on $22^{\text {nd }}$ August 2017].

Ajulor, V.O. (2013). Policy implementation and rural poverty reduction in Nigeria: An analysis of National Poverty Eradication Program (NAPEP) in Ado Odo Ota Local Government Area, Ogun State. European Scientific Journal, 9(19).

Al-Aini, B. (1990CE/1411AH). Al-Binayah fi Sharh al-Hidayah. Vol 10. P. 570-612. Second Edition. Dar al-Fikr. Beirut, Lebanon.

Al-Bukhari M. 194-256 A. H., (2008), The Authentic Hadith Collections, Mu'assasat al- Mukhtar. Cairo, Egypt.

Al-Harran, S.A. (1990). Islamic finance: The experience of the Sudanese Islamic Bank in partnership (musharakah) financing as a tool for rural development among small farmers in Sudan. (Doctoral dissertation, Durham University).

Egwemi, V. \& Odo, L.U. (2013). Rural development and poverty eradication in Nigeria. J. Res. Nat. Dev., 11, 101-110.

Ejike, O.L. (2012). Financing agriculture in Nigeria: Issues and solutions. Journal of Research of Pure and Applied Sciences, 1(1).

Ekeghe, M. (2016). Ogbeh: 1.6\% of Budget Not Enough for Agriculture Ministry. Thisday. [online] Available from: https://www.thisdaylive.com/index.php/2016/05/12/ogbeh-1-6-of-budgetnotenough-for agriculture-ministry/

Eze, C., Lemchi, J.I., Ugochukwu, A.I., Eze, V.C., Awulonu, \& Okon, A.X. (2010). Agricultural financing policies and rural development in Nigeria. In 84 Annual Conference, March 29-31, 2010, Edinburg, Scotland (No. 91677). Agricultural Economics Society.

Famogbiele, A. (2013). The challenges of agricultural finance in Nigeria: Constraints to sustainable agricultural and economic revival. International Journal of Business and Social Research (IJBSR), 3(5), 234-244.

[FAO] Food and Agriculture Organization (2008). Food security for action: A practical guide. Food and Agriculture Organization EC - FAO Food Security Program.

[FAO] Food and Agriculture Organization (2018). Crop prospects and food situation. GIEWS Global Information and Early Warning System on Food and Agriculture, Food and Agriculture Organization of the United Nation. Quaterly Global Report June 2018, ISBN 97892-5-13599-7

[GFSI] Global Food Security Index (2015). An annual measure of the state of global food security. The Economist Intelligence Unit.

Hakimi, M. (2011). Crafting the agricultural product and loss sharing (aPLS) in the place of the profit and loss (PLS) for Islamic agricultural finance. Kyoto Working Papers on Area Studies: G-COE Series, 114, 1-28.

Hakimi, M. (2011). Theory of "sharecropping" from an Islamic economic perspective: A study of alMuzāra'a \& al-Musaqat. Kyoto Bulletin of Islamic Area Studies, 4(1\&2), 190209.

Hassan, M.T., Sattar M.A., Tousif, M.A., Nasir, N., Sadiq, M., \& Yesmin, M. (2012). Role of Islamic banking in agriculture development in Bahawalpur, Pakistan. International Journal of Learning \& Development, 2(3), 123-138.

Ibn Manzur, d. 711AH/1411CE, (n.d.). Lisan al-Arab. P. 1826. Dar al-Ma'aarif Publishers, Cairo,Egypt.

Ibn Qudamah 541-620 A.H, (1997), al Mughni. Vol. 7. Bab al Muzara'ah. PP 555-572. Dar Alam alKutub, Riyadh, Saudi Arabia.

Ifeoma, J.I. \& Agwu A.E. (2014). Assessment of food security situation among farming households in rural areas of Kano state, Nigeria. Journal of Central European Agriculture, 15(1), 94-107. 
Inuwa, I.M.S., Kyiogwom, U.B., Ala, A.L., Maikasuwa, M.A., \& Ibrahim, N.D. (2011). Profitability analysis of rice processing and marketing in Kano State, Nigeria. Nigerian Journal of Basic and Applied Science, 19(2), 293-298.

Kano State (2013). A guide to business and investment in Kano State. Kano State Investors' Handbook.

Khasanah, U., Salim, U., Triyuwono, I., \& Irianto, G. (2013). The practice of profit and loss sharing system for rice farmers in East Java, Indonesia. International Research Journal of Finance and Economics, 9(3), 1-7.

Krejcie R.V. \& Morgan D.W. (1970). Determining sample size for research activities. Educational and Psychological Measurement, 30(3), 607-610.

Makarfi A.M. \& Olukosi J.O. (2012). Uses of fund and constraints to growth among microfinance institutions in Kano State, Nigeria. Journal of Development and Agricultural Economics, 4(1), $17-22$.

Ministry of Budget and National Planning (2016). Budget implementation monitoring and performance 2016 third quarter monitoring report. Abuja, Nigeria: Author

NBS (2010). Annual abstract of statistics. National Bureau of Statistics, Federal Republic of Nigeria, www.nigeriastat.gov.ng

NBS/MDG (2013). Statistical tables from the millennium development goals' survey. a collaborative survey between the office of special assistant to the president on MDGs and the national bureau of statistics.

Nienhaus, V. (2010). Capacity building in the financial sector: Strategies for strengthening financial institutions. In Inaugural Islamic Financial Stability Forum Khartoum, Sudan 6 April.

Nyagba, S. (2009). Review of the Nigerian rural development policy for sustainable growth. West African Regional Conference on Smart, appropriate technologies for rural communities, Abuja, Nigeria, July 9, 11.

Obansa, S.A.J. \& Maduekwe, I.M. (2013). Agriculture financing and economic growth in Nigeria. European Scientific Journal, 9(1).

Adebayo, P.F. \& Ojo, E.O. (2012). Food security in Nigeria: An overview. European Journal of Sustainable Development, 1(2), 199-221.

Okoro D. \& Ujah O.C. (2009). 'Agricultural policy budget analysis in Nigeria (1999-2007): perspective and implications for SLISSFAN project status'. Report Submitted to OXFAM GB Nigeria.

Rahman, A.A. \& Othman, P.F. (2012). The agricultural land tenancy contract from the Islamic perspective and its practice among farmers: A study in Selangor, Malaysia. African Journal of Agricultural Research, 7(10), 1584-1594.

Ruete M. (2015). Financing agriculture: How to boost opportunities in developing countries. Investment in Agriculture. Policy Brief, 3.

Sharbisi A., (1981 CE/1401 AH) Mu'jam al-Iqtisadi al-Islami. P. 418. Dar al-Jil Publishers.

Tahir, S. (1996). Riba, share-tenancy, and agrarian reforms. The Pakistan Development Review, 35(4), 989-1000.

The Hunger Program (2018). Know your world: Facts about hunger and poverty, http://www.thp.org/knowledge-center/know-your-world-facts-about-hunger-poverty/

The World Bank: Nigeria Data (2013, August 20). World Bank Development Indicators: Statistics in Africa: Data and Statistics. The World Bank and agriculture in Africa. Africa fact sheet (2013).

Yaacob, H. (2013). Commercializing muzara'ah model contract through Islamic finance to help Malaysian Aborigines. International Journal of Business, Economics, and Law, 2(3), 69-77.

Yakubu O.D. \& Aderonmu, J.A. (2010). Rural poverty alleviation and democracy in Nigeria's fourth republic. Current Research Journal of Social Sciences 2(3): 191-195.

Yusoff, M.M. \& Aziz, M.R.A. (2013). Shari'ah-compliant financing for agriculture in Islamic banking institutions. IE CONS-2013 Pdf.

Zuhaili, W., (1985 CE/1405 AH) Fiqh al Islami wa Adillatuhu. Vol. 5. PP. 613-654. Second Edition, Dar al Fikr. Damascus, Syria. 